\title{
Interactive relationship between plant growth and soil chemical properties in a mangrove afforestation stand, Kiribati
}

Tomomi Inoue ( $\nabla$ tomomi.inoue@nies.go.jp )

National Institute for Environmental Studies https://orcid.org/0000-0002-2276-4402

Yasuaki Akaji

Ayato Kohzu

Ko Hinokidani

Hiroshi Adachi

Mio Kezuka

Shigeyuki Baba

\section{Research Article}

Keywords: $\delta 13 \mathrm{C}, \delta 15 \mathrm{~N}$, nitrification, phosphorus mobilization, Rhizophora stylosa, soil pore water

Posted Date: February 23rd, 2022

DOI: https://doi.org/10.21203/rs.3.rs-1367430/v1

License: (a) (i) This work is licensed under a Creative Commons Attribution 4.0 International License. Read Full License 


\section{Abstract}

Purpose There is increased recognition of the importance of mangroves worldwide, with efforts being made to sustainably manage these ecosystems for forestry and fishery use. Although successive monitoring of mangrove growth after planting has been conducted in some afforestation stands, measurements of soil environmental changes accompanying the plant growth have not been made in most stands. In this study, we observed the interactive relationship between the growth of mangrove, Rhizophora stylosa, and soil chemical properties at an afforestation stand on Tarawa atoll, Kiribati.

Methods We first estimated root biomass in the stand. Next, we measured the concentrations of dissolved phosphorus, nitrogen, and other ions $\left(\mathrm{Br}^{-}, \mathrm{Ca}^{2+}, \mathrm{K}^{+}, \mathrm{Na}^{+}, \mathrm{Cl}^{-}\right.$, and $\left.\mathrm{SO}_{4}{ }^{2-}\right)$ in soil pore water, as well as the isotopic ratio of leaf carbon and nitrogen in patches of different plant ages.

Results Differences in salt stress among the patches were reflected in leaf $\delta^{13} \mathrm{C}$, suggesting it would be a good indicator of the physiological response of mangrove plants to salinity. Estimated root biomass was positively related with phosphate and nitrate concentrations in soil pore water, indicating the formation of a rhizosphere environment with the occurrence of root-microorganism interactions. Leaf $\delta^{15} \mathrm{~N}$ analysis suggested that the discrimination of nitrogen isotopes during nitrification and/or uptake of $\mathrm{NH}_{4}{ }^{+}$and $\mathrm{NO}_{3}{ }^{-}$occurs in accordance with plant growth.

Conclusions Our findings revealed the changes that occur in the chemical properties of mangrove leaves and soil pore water after mangrove plantation on a yearly basis, which can improve our understanding of environmental succession during the formation of mangrove ecosystems.

\section{Introduction}

The most distinctive feature of tropical tidal flats is that woody plants form deep forests called mangroves, whereas in temperate and cool regions herbaceous plants dominate tidal flats (Tomlinson 2016). Over the past few decades, mangroves have drawn a lot of interests from researchers in various fields, because these ecosystems offer a variety of benefits, such as timber productions, fisheries, nutrient cycling, and biodiversity (Baba et al. 2013). There is increased recognition of the importance of mangroves worldwide, and efforts have been made to sustainably manage these ecosystems for forestry and fishery use.

The carbon sequestration function of mangrove ecosystems has received attention from the perspective of climate change. Many reports suggest that mangrove soils contain a large amount of carbon (Donato et al. 2011; Atwood et al. 2017; Inoue 2018; Sanderman et al. 2018). Because the growth rates of mangrove plants, such as leaf and root production rates, are not that high compared with those of other terrestrial woody plants (Lin and Sternberg 1993; Farnsworth et al. 1996; Ball et al. 1997; Ellison and Farnstworth 1997; López-Hoffman et al. 2006; Inoue et al. 2022), the high carbon content of the soils may be related to the low rate of organic matter decomposition in the flooded saline soils (Miyajima and 
Hamaguchi 2018). The mangrove ecosystem's strong ability to sequester carbon could efficiently mitigate global warming, and thus mangrove afforestation and reforestation have been promoted in many tropical coastal areas (Kainuma et al. 2013). In addition, mangroves' protective function against coastal events such as storm waves and surges, whose frequency and magnitude are likely to increase under global warming, is another important feature helping to adapt the effects of climate change (Chang and Mori 2021).

With the promotion of mangrove afforestation and reforestation in many countries has come an increase in empirical knowledge regarding planting procedures and subsequent management (Field 1996; Kainuma et al. 2013; Ong and Gong 2013). Although successive monitoring of plant growth after planting has been conducted in some afforestation stands (Samson and Rollon 2008; Sillanpää et al. 2017), the soil environmental changes accompanying plant growth have not been measured in most stands. On the other hand, some field studies in natural mangrove forests have suggested that mangrove roots interact with nitrogen-fixing bacteria (Inoue et al. 2011a; Inoue et al. 2019; Inoue et al. 2020) and arbuscular mycorrhiza (Akaji et al. 2022). A cultivation experiment has revealed increases in phosphate ion $\left(\mathrm{PO}_{4}{ }^{-}\right)$ and ferrous ion $\left(\mathrm{Fe}^{2+}\right)$ concentrations in mangrove-rooted soil pore water (Inoue et al. 2011b), and a field study has noted high nitrate ion $\left(\mathrm{NO}_{3}{ }^{-}\right)$concentration near mangrove roots (Inoue et al. 2011a). These studies suggest that changes in soil biochemical properties can occur in mangrove afforestation areas. Indeed, such changes are the beginning of the formation of nutrient cycling in mangrove plantations, which will be closely related with primary production of the forests and thus forestry and fishery resources.

It can be difficult to decipher the plant root effects on soil chemistry in natural mangrove forests, in which many complex factors such as input from inland river water, leaching from accumulated organic matter, and unknown site history influence soil chemical properties. On Kiribati atoll, there is a mangrove afforestation stand for which we have detailed information, including what species, how many individuals, when, and where the material was planted. Furthermore, the atoll does not have a river, and the topographic relief of the afforestation stand is almost uniform, making it easier to detect the quantitative effects of mangrove plant roots on soil chemistry in the stand.

We conducted a field survey on the mangrove afforestation stand in Kiribati, where Rhizophora stylosa Griff. has been planted since 2005, with the aim of clarifying the following questions: What are the survival and growth of planted mangroves in the afforestation stand? Does mangrove root growth affect dissolved phosphorus and nitrogen in soil pore water of the stand? Do soil properties reflect mangrove leaf properties, such as $\delta^{13} \mathrm{C}$ and $\delta^{15} \mathrm{~N}$ ? To answer these questions, we first collected data on tree age, tree height, diameter, and density and then used the data to estimate root biomass by using an allometric equation. We then measured dissolved phosphorus and nitrogen concentrations in soil pore water in patches of different plant ages. Based on our analysis of the relationships among the variables, we discuss interactions between plant growth and soil chemical properties in the mangrove afforestation stand on Kiribati atoll. 


\section{Materials And Methods \\ Study site}

The survey was conducted at a mangrove afforestation stand on Tarawa atoll, Republic of Kiribati, in the Pacific $\left(1^{\circ} 27^{\prime} \mathrm{N}, 172^{\circ} 58^{\prime} \mathrm{E}\right)$ (Fig. 1a, b). According to the Climatic Research Unit of the University of East Anglia, mean annual temperature and precipitation at Tarawa during $1991-2020$ were $27.5^{\circ} \mathrm{C}$ and 1037 mm year ${ }^{-1}$ (https://climateknowledgeportal.worldbank.org/country/kiribati/climate-data-historical). The afforestation stand is located on the west inner bay side of Bonriki in Tarawa (Fig. 1c, d). The sand at the stand is typical of tidal flats in central Pacific atolls, mostly consisting of fine particles of carbonate. On the opposite side of the afforestation stand in between the causeway (Ananau Causeway) were abandoned ponds filled with rainwater (Fig. 1d). According to interviews with local people, the ponds had been abandoned since at least 2000 and not used for anything. 
Table 1

Tree age, size, density, and flowering of the Rhizophora stylosa afforestation stand on Tarawa, Republic of Kiribati in September 2019

\begin{tabular}{|c|c|c|c|c|c|c|c|}
\hline $\begin{array}{l}\text { Patch } \\
\text { ID }\end{array}$ & $\begin{array}{l}\text { Year and month } \\
\text { planted }\end{array}$ & $\begin{array}{l}\text { Tree } \\
\text { age } \\
\text { (years) }\end{array}$ & $\begin{array}{l}\text { Mean* } \\
\text { height } \\
\text { (cm) }\end{array}$ & $\begin{array}{l}\text { Mean* } \\
\text { diameter } \\
(\mathrm{mm})\end{array}$ & $\begin{array}{l}\begin{array}{l}\text { Tree } \\
\text { density }\end{array} \\
\left(\mathrm{m}^{-2}\right)\end{array}$ & $\begin{array}{l}\text { Occurrence of } \\
\text { flowering }\end{array}$ & $\begin{array}{l}\begin{array}{l}\text { Pore } \\
\text { water }\end{array} \\
\text { sampling } \\
\text { in this } \\
\text { study }\end{array}$ \\
\hline 1 & $2005 / 9$ & 14.0 & - & - & - & $\#$ & - \\
\hline 2 & $2008 / 3$ & 11.5 & - & - & - & $\#$ & - \\
\hline 3 & $2008 / 9$ & 11.0 & - & - & - & $\#$ & - \\
\hline 4 & $2008 / 9$ & 11.0 & $\begin{array}{l}223.9 \pm \\
32.8\end{array}$ & $\begin{array}{l}24.5 \pm \\
3.3\end{array}$ & 8.5 & \# & $\neq$ \\
\hline 5 & $2009 / 3$ & 10.5 & - & - & - & - & - \\
\hline 6 & $2009 / 9$ & 10.0 & $\begin{array}{l}274.6 \pm \\
18.3\end{array}$ & $\begin{array}{l}25.4 \pm \\
4.3\end{array}$ & 6.6 & \# & - \\
\hline 7 & $2010 / 3$ & 9.5 & $\begin{array}{l}277.6 \pm \\
29.1\end{array}$ & $\begin{array}{l}23.9 \pm \\
4.1\end{array}$ & 11.6 & \# & - \\
\hline 8 & $2011 / 2$ & 8.6 & $\begin{array}{l}150.9 \pm \\
23.7\end{array}$ & $\begin{array}{l}22.8 \pm \\
3.5\end{array}$ & 14.3 & $\#$ & - \\
\hline 9 & $2011+$ & $\begin{array}{l}8.0- \\
9.0\end{array}$ & - & - & - & - & - \\
\hline 10 & $2012 / 9$ & 7.0 & $\begin{array}{l}198.0 \pm \\
18.3\end{array}$ & $\begin{array}{l}21.3 \pm \\
2.7\end{array}$ & 14.3 & \# & $\ddagger$ \\
\hline 11 & $2013 / 2$ & 6.6 & $\begin{array}{l}197.2 \pm \\
37.3\end{array}$ & $\begin{array}{l}20.0 \pm \\
2.4\end{array}$ & 14.9 & \# & - \\
\hline 12 & $2013 / 10$ & 5.9 & $\begin{array}{l}97.6 \pm \\
18.0\end{array}$ & $\begin{array}{l}19.4 \pm \\
2.2^{2}\end{array}$ & 6.3 & & - \\
\hline 13 & $2014 / 1$ & 5.7 & $\begin{array}{l}147.1 \pm \\
25.4\end{array}$ & $\begin{array}{l}18.4 \pm \\
2.6\end{array}$ & 11.4 & \# & - \\
\hline 14 & $2014 / 9$ & 5.0 & $\begin{array}{l}88.9 \pm \\
7.1\end{array}$ & $\begin{array}{l}17.0 \pm \\
2.7\end{array}$ & 3.8 & & - \\
\hline 15 & $2015 / 1$ & 4.7 & $\begin{array}{l}130.2 \pm \\
18.0\end{array}$ & $\begin{array}{l}18.6 \pm \\
1.9\end{array}$ & 10.1 & $\#$ & $\ddagger$ \\
\hline 16 & $2015 / 1$ & 4.7 & - & - & - & $\#$ & - \\
\hline 17 & $2015 / 10$ & 4.1 & - & - & - & - & - \\
\hline 18 & $2016 / 1$ & 3.7 & - & - & - & & - \\
\hline
\end{tabular}




\begin{tabular}{|c|c|c|c|c|c|c|c|}
\hline $\begin{array}{l}\text { Patch } \\
\text { ID }\end{array}$ & $\begin{array}{l}\text { Year and month } \\
\text { planted }\end{array}$ & $\begin{array}{l}\text { Tree } \\
\text { age } \\
\text { (years) }\end{array}$ & $\begin{array}{l}\text { Mean* } \\
\text { height } \\
\text { (cm) }\end{array}$ & $\begin{array}{l}\text { Mean* } \\
\text { diameter } \\
(\mathrm{mm})\end{array}$ & $\begin{array}{l}\begin{array}{l}\text { Tree } \\
\text { density }\end{array} \\
\left(\mathrm{m}^{-2}\right)\end{array}$ & $\begin{array}{l}\text { Occurrence of } \\
\text { flowering }\end{array}$ & $\begin{array}{l}\text { Pore } \\
\text { water } \\
\text { sampling } \\
\text { in this } \\
\text { study }\end{array}$ \\
\hline 19 & $2016 / 9$ & 3.0 & $\begin{array}{l}82.1 \pm \\
7.3\end{array}$ & $\begin{array}{l}16.9 \pm \\
2.7\end{array}$ & 6.0 & & $\neq$ \\
\hline 20 & $2017 / 9$ & 2.0 & - & - & - & & - \\
\hline
\end{tabular}

Almost every year since 2005, propagules of $R$. stylosa collected from the natural forest at Tanaea have been planted on the afforestation site by the International Society for Mangrove Ecosystems (ISME) (Fig. 1d). Propagules have been densely planted, with three propagules per group planted at a spacing of 50 $\mathrm{cm} \times 50 \mathrm{~cm}$, in order to avoid failure during early growth due to strong soil water evaporation (Baba 2011). This dense planting method has been empirically established and used in many mangrove afforestation efforts in other countries (Kainuma et al. 2013). In 2019, the stand was about $10,500 \mathrm{~m}^{2}$ and had 19 patches with plants of different ages (Fig. 1e, Fig. S1). Using records of the number of planted propagules and planting location and date for all patches, we made an age map of the afforestation stand (Table 1, Fig. 1e).

\section{Measurement of tree size and survival rate}

Tree size and survival rate were measured in 11 of the 19 patches differing in plant age. We used the data of tree height $(H, \mathrm{~cm})$ and diameter $(D, \mathrm{~cm})$ reported in Mori et al. (2022), which were measured in 2019 (Table 1). In each patch, two or three $2 \mathrm{~m} \times 2 \mathrm{~m}$ square subplots were randomly chosen, and the number of trees surviving within each subplot was measured.

Root biomass ( $W, \mathrm{~kg}$ dry weight $\left.\mathrm{m}^{-2}\right)$ was estimated by using of the allometric equation for $R$. stylosa (Comley and McGuinness 2005):

$W=\left(\sum_{i=0}^{n} 0.261 D_{i}^{1.86}\right) / A(1)$,

where $i$ indicates individual tree, and $A$ indicates the subplot area $\left(4 \mathrm{~m}^{2}\right)$.

Tree density was obtained by dividing the number of surviving trees $(S)$ by the subplot area. Occurrence of flowering was recorded in all 19 patches.

\section{Sampling and analysis of leaves and soil pore water}

Leaf samples were taken in the 11 patches where tree size $(H$ and $D)$ and survival $(S)$ were measured. The second youngest pair of leaves, which were mature, were collected from five randomly selected 
individuals in each patch. The sampled leaves were stored in dry silica gel during the 5-day transport to the laboratory in Japan. In the laboratory, the leaves were dried at $80^{\circ} \mathrm{C}$ until their weight become constant. The dried leaves were then ground into fine powder, $10 \mathrm{mg}$ of each sample was wrapped in tin foil, and nitrogen and carbon contents were measured with an elemental analyzer (Flash EA 1112, Thermo Electron Corp., Minneapolis, MN, USA). The precision (SD for $N>5$ ) of $\mathrm{N} w t \%$ and $\mathrm{C}$ wt\% was < $0.01 \%$ and $0.1 \%$, respectively. Each sample was measured three times and the mean value was determined.

Another 2-3 mg of leaf powder sample was wrapped in an aluminum cup, and ${ }^{15} \mathrm{~N}$ and ${ }^{13} \mathrm{C}$ contents were measured by using a continuous-flow isotope ratio mass spectrometer coupled with an elemental analyzer (CF/IRMS, system: FlashEA1112/Conflolll/Deltaplus Advantage, Thermo Finnigan, San Jose, CA, USA). Stable isotope ratios are expressed in $\delta$ notation as the difference in parts per thousand (\%o) from the standard (atmospheric $\mathrm{N}_{2}$ for $\delta^{15} \mathrm{~N}$ and PDB for $\delta^{13} \mathrm{C}$ ):

$\delta^{15} \mathrm{~N}=\left[\left({ }^{15} \mathrm{~N} /{ }^{14} \mathrm{~N}\right)_{\text {sample }} /\left({ }^{15} \mathrm{~N} /{ }^{14} \mathrm{~N}\right)_{\text {standard }}-1\right] \times 1000(2)$

$\delta^{13} \mathrm{C}=\left[\left({ }^{13} \mathrm{C} /{ }^{12} \mathrm{C}\right)_{\text {sample }} /\left({ }^{13} \mathrm{C} /{ }^{12} \mathrm{C}\right)_{\text {standard }}-1\right] \times 1000(3)$

We used D,L-alanine $\left(\delta^{15} \mathrm{~N}=-1.7 \%\right.$, $\delta^{13} \mathrm{C}=-23.47 \%$, $\mathrm{N}$ wt $\left.\%=15.73, \mathrm{C} w \mathrm{wt}=40.45\right)$ and glycine $\left(\delta^{15} \mathrm{~N}\right.$ $=2.6 \%, \delta^{13} \mathrm{C}=-19.24 \%$ o, $\left.\mathrm{N} w t \%=18.65, \mathrm{C} w t \%=31.97\right)$ as internal laboratory standards. The precision (SD for $N>5$ ) of the ${ }^{15} \mathrm{~N}$ and ${ }^{13} \mathrm{C}$ isotopic ratio was $\pm 0.3-0.5 \%$ o and $\pm 0.1-0.15 \%$, respectively.

Soil pore water was collected from 4 of the 19 planted patches and from a control patch where mangroves were not planted (control, 4, 10, 15, and 19 in Fig. 1e). At low tide, five soil samples containing pore water were collected by using a stainless core sampler ( $6 \mathrm{~cm}$ diameter $\times 25 \mathrm{~cm}$ length). For each core, the sample at $20-25 \mathrm{~cm}$ soil depth was placed in a plastic bag and stored in an ice-filled container (kept at $0^{\circ} \mathrm{C}$ ). Twenty milliliters of each sample were transferred into a centrifugal device with a $0.45 \mu \mathrm{m}$ pore membrane (MAPM45C68, Pall Corp., Tokyo, Japan), which was run at $3000 \mathrm{rpm}$ for $5 \mathrm{~min}$ to collect soil pore water. The obtained soil pore water was passed through a $0.2-\mu \mathrm{m}$ pore filter (DISMIC-25CS, Toyo Roshi, Tokyo, Japan) and stored at $4^{\circ} \mathrm{C}$ until analysis.

Dissolved total nitrogen (DTN), dissolved organic nitrogen (DON), $\mathrm{NH}_{4}{ }^{+}, \mathrm{NO}_{3}{ }^{-}$, dissolved total phosphorus (DTP), dissolved organic phosphorus (DOP), and $\mathrm{PO}_{4}{ }^{-}$were measured using a colorimetric auto analyzer (Traacs 800, Bran + Luebbe, Tokyo, Japan). Six species of other major ions $\left(\mathrm{Br}^{-}, \mathrm{Ca}^{2+}, \mathrm{K}^{+}, \mathrm{Na}^{+}, \mathrm{Cl}^{-}\right.$, and $\mathrm{SO}_{4}{ }^{2-}$ ) were analyzed via ion chromatography (DX-320, EG40, Dionex, Tokyo, Japan). Analytical precision (SD for $N=5$ ) was better than $0.21 \mathrm{mg} \mathrm{L}^{-1}$ for $\mathrm{NH}_{4}{ }^{+}-\mathrm{N}, 3.3 \mu \mathrm{g} \mathrm{L}^{-1}$ for $\mathrm{NO}_{3}{ }^{-}-\mathrm{N}$, and $0.1-0.3 \mu \mathrm{g} \mathrm{L}^{-1}$ for $\mathrm{PO}_{4}{ }^{-}$-P. The detection limits for major ions were $0.26 \mathrm{mg} \mathrm{L}^{-1}$ for $\mathrm{Na}^{+} ; 0.08-0.10 \mathrm{mg} \mathrm{L}^{-1}$ for $\mathrm{Ca}^{2+}, \mathrm{Mg}^{2+}$, $\mathrm{Cl}^{-} ; 0.04 \mathrm{mg} \mathrm{L}^{-1}$ for $\mathrm{SO}_{4}{ }^{2-}$; and $0.01-0.03 \mathrm{mg} \mathrm{L}^{-1}$ for others.

\section{Statistical analysis}


Tree size, survival rate, leaf carbon and nitrogen contents, and soil pore water characteristics were measured in 11 patches differing in plant age in the mangrove afforestation stand on Tarawa. The statistical analyses were performed using R v. 3.5.2 (R Core Team 2018). To explain the relationship between variables (tree age, estimated root biomass, soil salinity, nutrient concentration in soil pore water, leaf carbon, leaf $\delta^{13} \mathrm{C}$, leaf nitrogen, and leaf $\delta^{15} \mathrm{~N}$ ), we conducted a generalized linear mixed model (GLMM) analysis in which individual patches were treated as random factors. A gamma distribution with inverse link function was used with the "glmer" function from the "Ime4" R package (Bates et al. 2015) for data shown in Figs. 2-5. A Gaussian distribution with identity link functions was used with the "Imer" function from the "Ime4" R package for data shown in Figs. 6 and 7. Centering was conducted for explanatory variables. For nutrient concentrations, an order of magnitude lower than the detection limit was assigned for the value of zero. Candidate models that differed with respect to the combination of explanatory variables (null, linear, and second-order regression) were ranked based on their Akaike Information Criterion (AIC) scores, and the model that exhibited the lowest score among prior candidate models was selected as the best-fit model for the response variable (Burnham and Anderson 2002).

\section{Results}

\section{Tree size, survival, and flowering}

Mean tree height and diameter both increased with the increment of tree age (Table 1). In the patch with 7.0-year-old trees, mean height was almost $200 \mathrm{~cm}$ and mean diameter more than $2 \mathrm{~cm}$; flowering first occurred when trees had reached 4.7 years of age (Table 1 ). The surviving tree density ranged from 3.8 to $14.9 \mathrm{~m}^{-2}$ and varied among the patches (Table 1). The estimated root biomass per area derived by Eq. (1) ranged from 3.2 to $17.4 \mathrm{~kg} \mathrm{~m}^{-2}$ and was highest in the 8.6-year-old trees (patch 8). The selected model for the estimated root biomass was a function of tree age (Fig. 2, Table S1).

\section{Salinity}

Although the afforestation stand appeared to be uniformly flat, the $\mathrm{Na}^{+}$concentration of soil pore water ranged from 11.1 to $14.8 \mathrm{~g} \mathrm{~L}^{-1}$ among the patches (Fig. 3). There were good correlations between concentrations of $\mathrm{Na}^{+}$and other sea water-related ions $\left(\mathrm{Br}^{-}, \mathrm{Ca}^{2+}, \mathrm{Cl}^{-}, \mathrm{K}^{+}, \mathrm{Mg}^{2+}\right.$, and $\left.\mathrm{SO}_{4}{ }^{2-}\right)$, indicating that the salinity condition due to sea water incursion differed slightly among the patches (Fig. S2). Among the 5 patches where we collected soil pore water, the $\mathrm{Na}^{+}$concentration of soil pore water was highest in the patch with 7.0-year-old trees (patch 10). The fitted curve for $\mathrm{Na}^{+}$concentration of soil pore water was a function of estimated root biomass, indicating that salinity became higher in afforested patches with higher mangrove root biomass (Fig. 3, Table S1), but it was not clear whether tree growth caused the salinity increment or not.

\section{Dissolved phosphorus and nitrogen in soil pore water}


Of the dissolved total phosphorus (DTP) in soil pore water, the organic phosphorus (DOP) concentration was 1.2-9.7 times higher than the inorganic phosphorus $\left(\mathrm{PO}_{4}^{-}-\mathrm{P}\right)$ concentration (Fig. $4 \mathrm{a}-\mathrm{C}$ ). The $\mathrm{PO}_{4}^{-}{ }^{-} \mathrm{P}$ concentration in soil pore water increased significantly with the increment of estimated mangrove root biomass, but there was no relationship between mangrove root biomass and the DOP concentration (Fig. $4 \mathrm{~b}$ and $\mathrm{c}$, Table S1). The $\mathrm{PO}_{4}{ }^{-}-\mathrm{P}$ :DTP-P ratio in soil pore water increased significantly with the increment of estimated root biomass (Fig. 4d, Table S1).

Of the dissolved total nitrogen (DTN) in soil pore water, the organic nitrogen (DON) concentration was mostly lower than the inorganic nitrogen $\left(\mathrm{NH}_{4}{ }^{+}-\mathrm{N}\right.$ and $\left.\mathrm{NO}_{3}{ }^{-}{ }^{-} \mathrm{N}\right)$ concentration: the DON concentration was 0.1-2.8 times that of the inorganic nitrogen concentration (Fig. 5a-d). The $\mathrm{NO}_{3}{ }^{-}-\mathrm{N}$ concentration in soil pore water increased as a quadratic function of the estimated mangrove root biomass, whereas no relationship existed between mangrove root biomass and $\mathrm{NH}_{4}{ }^{+} \mathrm{N}$ and DON concentrations (Fig. 5b-d). The $\mathrm{NO}_{3}{ }^{-}-\mathrm{N}: \mathrm{NH}_{4}{ }^{+}-\mathrm{N}$ ratio in soil pore water increased as a quadratic function of the estimated root biomass (Fig. 5e, Table S1).

\section{Leaf carbon and nitrogen isotopic signatures}

There was no relationship between tree age and leaf $\delta^{13} \mathrm{C}$ (Fig. 6a, Table S1). However, leaf $\delta^{13} \mathrm{C}$ was significantly higher at the patches where the $\mathrm{Na}^{+}$concentration of soil pore water was high, suggesting that the salinity condition had affected stomatal conductance of mangrove leaves in the stand (Fig. 7a). The selected model was a quadratic function of $\mathrm{Na}^{+}$concentration in soil pore water (Table S1). As for leaf carbon content, no relation with tree age was found (Fig. 6c, Table S1).

Leaf $\delta^{15} \mathrm{~N}$ increased with tree age (Fig. $6 \mathrm{~b}$, Table S1), and it was significantly higher at the patches where the $\mathrm{Na}^{+}$concentration of soil pore water was high (Fig. 7b) and where the $\mathrm{NO}_{3}{ }^{-}-\mathrm{N}^{-} \mathrm{NH}_{4}{ }^{+}-\mathrm{N}$ ratio of soil pore water was high (Fig. 7c). Thus, it appears that the nitrogen source for plant growth had changed with tree age and/or sea water had affected leaf $\delta^{15} \mathrm{~N}$ in the stand. The null model was selected for the relationship between leaf nitrogen content and tree age (Fig. 6d, Table S1), whereas the leaf C:N ratio increased with tree age (Fig. 6e, Table S1), suggesting a limitation of nitrogen uptake occurred with tree ageing in the stand.

\section{Discussion}

\section{Interaction between salinity and mangrove growth}

It has been long debated whether mangrove plants require salinity for their growth or not (Wang et al. 2011; Tomlinson 2016). Some studies have shown that mangrove plants grow in fresh water for long periods both under cultivation (McMillan 1971; Atreya et al. 2009) and field conditions (Van Steenis 1984; Woodroffe 1988; Aburto-Oropeza et al. 2021), whereas others have reported that mangrove plants are unable to grow without salinity over the long term (Downton 1982; Clough 1984; Werner and Stelzer 
1990). Still other studies suggest that mangrove plants, including Rhizophora species, optimize their growth rate under moderately saline conditions (i.e., 5-50\% sea water, depending on species; Clough 1984; Ball 1988; Lin and Sternberg 1993; Khan and Aziz 2001; López-Hoffman et al. 2006; Wang et al. 2011). Salinity of the soil pore water in this study was much higher, ranging from $83-111 \%$ that of sea water, which exceeds the previously suggested salinity for optimum growth. Thus, the growth of mangrove plants in the stand was likely suppressed by high salt stress. Such a high salinity may be due to the absence of freshwater input from a river and strong water evaporation during low tide, which are typical features of tidal flats on tropical atoll islands. Salinity stress causes low stomatal conductance, which results in low carbon uptake and transpiration rates at leaves (Ball and Farquhar 1984; Khan and Aziz 2001; Parida et al. 2004). Stomatal conductance can be estimated by leaf $\delta^{13} \mathrm{C}$, which increases under low intercellular/ambient ratios of $\mathrm{CO}_{2}$ partial pressure (Ehleringer and Cooper 1988, Hanba et al. 2010). The increase of leaf $\delta^{13} \mathrm{C}$ under high $\mathrm{Na}^{+}$concentration in soil pore water (Fig. 7a) suggests that discrimination of carbon isotopes was suppressed because of low stomatal conductance. The selected model for the relationship between $\mathrm{Na}^{+}$concentration in soil pore water and leaf $\delta^{13} \mathrm{C}$ was a quadratic function of $\mathrm{Na}^{+}$concentration (Table S1). These findings suggest that a decline of the $\mathrm{CO}_{2}$ assimilation rate suppressed the enhancement of leaf $\delta^{13} \mathrm{C}$ at the highest $\mathrm{Na}^{+}$concentration.

We observed that salinity was higher at the patches where estimated root biomass was higher (Fig. 3), but we cannot exclude the possibility that the afforestation had begun where salinity was originally high. The other possibility is that growth of plants itself had created high salinity of soil pore water. First, more sea water may be retained in a rooted soil structure than in an unrooted soil under low tide conditions, which could explain the observed salinity. Second, some mangrove plant species have adapted to a saline environment by salt exclusion at the roots, salt secretion through salt glands, and salt sequestration into senescent leaves (Scholander et al. 1962; Scholander 1968; Tomlinson 2016). Rhizophora species do not have salt glands, but they keep the salinity of xylem sap water low by ultrafiltration at the membranes of root cells (Scholander et al. 1966), which are able to filter up to $99 \%$ of salt from the surrounding soil pore water (Scholander 1968). This could concentrate salinity around roots (Passioura et al. 1992). The strong correlations between $\mathrm{Na}^{+}$and other sea water-related elements in the soil pore water (Fig. S2) suggests that observed high salinity in the stand was due mainly to the fact that more sea water may be retained in a rooted soil structure. The effect of salt exclusion at the roots, however, could concurrently occur at a small scale.

\section{Root growth and dissolved phosphorus in soil pore water}

Most phosphorus in soils is immobilized by adsorbing onto Fe-and/or Al-oxides, calcium compounds, and polymerized organic matter (Raymond et al. 2021), and phosphorus in mangrove sediments is no exception (Paludan and Morris 1999; Prasad and Ramanthan 2010). The immobilized phosphorus is released as inorganic phosphorus $\left(\mathrm{PO}_{4}^{-}\right)$by chelation with organic acids from plant roots and/or phosphorus-solubilizing microorganisms (Gyaneshwar et al. 2002; Raymond et al. 2021). Phosphorussolubilizing microorganisms were detected in some mangrove sediments (Vazquez et al. 2000; 
Kothamasi et al. 2006; El-Tarabily and Youssef 2010), and an increase in $\mathrm{PO}_{4}{ }^{-}$in mangrove-rooted soil has been reported in a cultivation experiment (Inoue et al. 2011b). Our observation of a positive relationship between estimated mangrove root biomass and $\mathrm{PO}_{4}{ }^{-}$concentration in soil pore water supports these findings. The continuous increment of $\mathrm{PO}_{4}{ }^{-}$concentration in soil pore water suggests that phosphorus-related processes, including input (phosphorus mobilization) and output (phosphorus immobilization and plant uptake), had not reached a static state over 11 years in the stand.

\section{Root growth and dissolved nitrogen in soil pore water}

Wetland soils, including mangrove soils, are generally hypoxic, with a greater amount of $\mathrm{NH}_{4}{ }^{+}$in soil pore water than $\mathrm{NO}_{3}{ }^{-}$(Alongi et al. 1992), as was the case in this study. We observed that the $\mathrm{NO}_{3}{ }^{-}$ concentration in soil pore water became higher with an increase in the estimated mangrove root biomass, suggesting the occurrence of nitrification around roots. Mangrove plants have an aerial root system, which is composed of partially exposed roots with lenticels (small pores on the root surfaces) (Tomlinson 2016). Atmospheric air is taken into the root via the lenticels, diffuses to buried root tips through aerenchymatous lacunae (Tomlinson 2016; Inoue et al. 2019), and is released to surrounding soils, producing an oxic-anoxic mosaic (Pi et al. 2009; Pi et al. 2010). This aeration system could stimulate nitrification in the rhizosphere. In our study stand, $\mathrm{NO}_{3}{ }^{-}$was detected in patches with trees that were $>4.7$ years old with root biomass $>5 \mathrm{~kg} \mathrm{~m}^{-2}$. The fact that the selected model for $\mathrm{NO}_{3}{ }^{-}$in soil water was a quadratic function of the estimated root biomass suggests that output processes of $\mathrm{NO}_{3}{ }^{-}$in soil water, such as denitrification and plant $\mathrm{NO}_{3}{ }^{-}$uptake, increased with greater root biomass. Some studies have shown that mangrove plants induce nitrate reductase in the presence of $\mathrm{NO}_{3}{ }^{-}$, indicating mangrove plants can assimilate $\mathrm{NO}_{3}{ }^{-}-\mathrm{N}$ (Ye et al. 2003; Parida and Das 2004). As observed in many mangroves (Alongi et al. 1992), the dissolved nitrogen concentration in soil pore water in the Kiribati stand was low compared with terrestrial wetland soils. The low nitrogen and high plant density could be reflected in the increment of the $\mathrm{C}: \mathrm{N}$ ratio of mangrove leaves, suggesting that plant growth was limited by nitrogen uptake.

\section{Changes of leaf $\delta^{15} \mathrm{~N}$ with tree age}

As tree age increased, leaf $\delta^{15} \mathrm{~N}$ rose to about $5 \%$ o in the 11 -year-old trees (Fig. $6 \mathrm{~b}$ ), suggesting that the source of nitrogen for plant growth had changed in accordance with tree age. The fact that leaf $\delta^{15} \mathrm{~N}$ was higher both where the $\mathrm{Na}^{+}$concentration and ratio of $\mathrm{NO}_{3}{ }^{-}-\mathrm{N} \mathrm{NH}_{4}{ }^{+} \mathrm{N}$ in soil pore water were high (Fig. 7b,

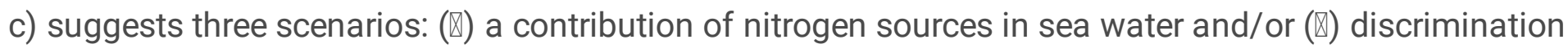
of nitrogen isotopes during nitrification and/or ( $\mathbb{Q}$ ) discrimination of nitrogen isotopes during uptake of $\mathrm{NH}_{4}{ }^{+}$and $\mathrm{NO}_{3}{ }^{-}$affected the leaf $\delta^{15} \mathrm{~N}$. Scenario (区), however, was unlikely because the $\delta^{15} \mathrm{~N}$ of sea sediments are in the range of 4-9\%o (Peters et al. 1978; Wada et al. 1987; Middelburg and Nieuwenhuize 1998). Our data indicated that a $5 \%$ increment in leaf $\delta^{15} \mathrm{~N}$ occurred by enhancement of $1 \% \mathrm{Na}^{+}$in soil pore water, meaning that the $\delta^{15} \mathrm{~N}$ of nitrogen sources in sea water were about $50 \%$ o higher than those of 
inland water. With regard to scenario $(\mathbb{\nabla})$, discrimination of nitrogen isotopes during nitrification $\left(\mathrm{NH}_{4}{ }^{+} \rightarrow\right.$ $\mathrm{NO}_{3}{ }^{-}$) under a micro-aerophilic condition results in ${ }^{15} \mathrm{~N}$ accumulation in residual $\mathrm{NH}_{4}{ }^{+}$(Brandes and Devol 1997; Freudenthal et al. 2001), and the increment of leaf $\delta^{15} \mathrm{~N}$ could be caused by the uptake of the $\mathrm{NH}_{4}{ }^{+}$. As for scenario (区), discrimination of nitrogen isotopes during uptake of $\mathrm{NH}_{4}{ }^{+}$and $\mathrm{NO}_{3}{ }^{-}$, in which the $\delta^{15} \mathrm{~N}$ of the plant body is increased with $\mathrm{NO}_{3}{ }^{-}$uptake, has been reported in other wetland plants (Mariotti et al. 1982; Handly and Ravan 1992; Yoneyama 1995; Yoneyama et al. 2001; Kohzu et al. 2008). Further measurements of the pore water $\delta^{15} \mathrm{~N}$ will help to clarify the mechanisms on the leaf $\delta^{15} \mathrm{~N}$ change in $R$. stylosa in the afforestation stand.

\section{Conclusions}

In this study, we observed the relationships between growth of the mangrove $R$. stylosa and soil chemical properties including salinity, dissolved phosphorus, and nitrogen at an afforestation stand on Kiribati atoll. Although the differences of salinity in the soil pore water among the patches were small (ranging from $83-111 \%$ sea water), our analyses indicated that the difference of the effect of salt stress on leaf stomatal conductance could be seen by measuring leaf $\delta^{13} \mathrm{C}$. Thus, leaf $\delta^{13} \mathrm{C}$ can serve as a good indicator of the physiological response of $R$. stylosa to salinity. Root biomass of $R$. stylosa was linked to increments of $\mathrm{PO}_{4}{ }^{-}$and nitrification, suggesting the formation of a rhizosphere environment where roots supply organic matter into the soil and root-microorganism interactions occur. Mangrove habitats generally have low phosphorus and nitrogen contents, such that these functions are adaptive for mangrove plants. Our leaf $\delta^{15} \mathrm{~N}$ data suggested that discrimination of nitrogen isotopes during nitrification and/or during uptake of $\mathrm{NH}_{4}{ }^{+}$and $\mathrm{NO}_{3}{ }^{-}$had occurred. Further studies on isotopic nitrogen in soil pore water should help to reveal the underlying mechanisms of the changes in leaf $\delta^{15} \mathrm{~N}$.

\section{Abbreviations}

Dissolved total nitrogen (DTN), dissolved organic nitrogen (DON), dissolved total phosphorus (DTP), dissolved organic phosphorus (DOP)

\section{Declarations}

Acknowledgements

We offer our sincere thanks to Mr. Anote Tong, the former president, and the director and officers of the Ministry of Environment, Lands and Agriculture Development of the Republic of Kiribati for giving us the research permission (Scientific Research Permit no. 012/16) and supporting our field activities. We also thank Mr. Minoru Abe (Alice Enterprises Inc., Kiribati) for his logistical and moral support.

\section{Funding}


This work was partly supported by JSPS KAKENHI (grant no. 16H04941) and by the Environment Research and Technology Development Fund Project (nos. JPMEERF20172012 and JPMEERF15S11406) of the Environmental Restoration and Conservation Agency of Japan.

\section{Competing Interests}

The authors have no competing interests to declare that are relevant to the content of this article.

\section{Author contributions}

Tomomi Inoue design the research, and Tomomi Inoue, Yasuaki Akaji, Ko Hinokidani, Hiroshi Adachi, Mio Kezuka, and Shigeyuki Baba conducted field measurements. Tomomi Inoue and Ayato Khozu conducted sample analysis. Tomomi Inoue and Yasuaki Akaji conducted statistical analysis of the data. All authors discussed and interpreted of the data and contributed to drafting and finalizing the manuscript.

\section{Data Availability}

The datasets generated during the current study are available from the corresponding author on reasonable request.

\section{References}

1. Aburto-Oropeza O, Burelo-Ramos CM, Ezcurra E, Ezcurra P, Henriquez CL, Vanderplank SE, Zapata F (2021) Relict inland mangrove ecosystem reveals Last Interglacial Sea levels. Proc Natl Acad Sci USA 118:e2024518118

2. Akaji Y, Inoue T, Taniguchi T, Baba S (2022) Arbuscular mycorrhizal fungal communities of a mangrove forest along a salinity gradient on Iriomote Island. Plant Soil. http://doi.org/10.1007/s11104-021-05193-4

3. Alongi DM, Boto KG, Robertson Al (1992) Nitrogen and phosphorus cycles. In: Robertson Al, Alongi DM (eds) Tropical mangrove ecosystems. American Geophysical Union, Washington, USA, pp 251292

4. Atreya A, Vartak V, Bhargava S (2009) Salt priming improves tolerance to desiccation stress and to extreme salt stress in Bruguiera cylindrica. Int J Integr Biol 6:68-73

5. Atwood TB, Connolly RM, Almahasheer H, Carnell PE, Duarte CM, Lewis CJE, Irigoien X, Kelleway JJ, Lavery PS, Macreadie PI, Serrano O, Sanders CJ, Santos I, Steven ADL, Lovelock CE (2017) Global patterns in mangrove soil carbon stocks and losses. Nat Clim Change 7:523-528

6. Baba S (2011) Close group planting of mangroves on atolls and coral islands of the Pacific. ISME/GLOMIS 9:11-12

7. Baba S, Chan HT, Aksornkoae S (2013) Useful products from mangrove and other coastal plants. ISME Mangrove Educational Book Series No. 3. International Society for Mangrove Ecosystems (ISME), Okinawa, Japan, and International Tropical Timber Organization (ITTO), Yokohama, Japan 
8. Ball MC (1988) Ecophysiology of mangroves. Trees 2:129-142

9. Ball MC, Farquhar MC (1984) Photosynthetic and stomatal responses of two mangrove species, Aegiceras corniculatum and Avicennia marina, to long term salinity and humidity conditions. Plant Physiol 74:7-11

10. Ball MC, Cochrane MJ, Rawson HM (1997) Growth and water use of the mangroves Rhizophora apiculata and $R$. stylosa in response to salinity and humidity under ambient and elevated concentrations of atmospheric $\mathrm{CO}_{2}$. Plant Cell Environ 20:1158-1166

11. Bates D, Mächler M, Bolker BM, Walker SC (2015) Fitting linear mixed-effects models using Ime4. J Stat Softw 67:1-48

12. Brandes JA, Devol AH (1997) Isotopic fractionation of oxygen and nitrogen in coastal marine sediments. Geochim Cosmochim Acta 61:1793-1801

13. Burnham KP, Anderson DR (2002) Model Selection and Multimodel Inference, 2nd edn. New York, Springer

14. Chang CW, Mori N (2021) Green infrastructure for the reduction of coastal disasters: a review of the protective role of coastal forests against tsunami, storm surge, and wind waves. Coast Eng $\mathrm{J}$ 63:370-385

15. Comley BWT, McGuinness KA (2005) Above- and below-ground biomass and allometry of four common northern Australian mangroves. Aust J Bot 53:431-436

16. Clough BF (1984) Growth and salt balance of the mangroves Avicennia marina and Rhizophora stylosa in relation to salinity. Aust J Plant Physiol 11:419-430

17. Donato DC, Kauffman JB, Murdiyarso D, Kurnianto S, Stidham M, Kanninen M (2011) Mangroves among the most carbon-rich forests in the tropics. Nat Geosci 4:293-297

18. Downton WJS (1982) Growth and osmotic relations of the mangrove, Avicennia marina, as influenced by salinity. Aust J Plant Physiol 9:519-528

19. Ehleringer JR, Cooper TA (1988) Correlations between carbon isotope ratio and microhabitat in desert plants. Oecologia 76:562-566

20. Ellison AM, Farnsworth EJ (1997) Simulated sea level change alters anatomy, physiology, growth and reproduction of red mangroves (Rhizophora mangle L.). Oecologia 112:435-446

21. El-Tarabily KA, Youssef T (2010) Enhancement of morphological, anatomical and physiological characteristics of seedlings of the mangrove Avicennia marina inoculated with a native phosphatesolubilizing isolate of Oceanobacillus picturae under greenhouse conditions. Plant Soil 332:147-162

22. Farnsworth EJ, Ellison AM, Gong WK (19969 Elevated $\mathrm{CO}_{2}$ alters anatomy, physiology, growth, and reproduction of red mangrove (Rhizophora mangle L.).Oecologia108:599-609

23. Field CD (1996) Restoration of mangrove ecosystems. International Society for Mangrove Ecosystems (ISME), Okinawa, Japan

24. Freudenthal T, Wagner T, Wenzhöfer F, Zabel M, Wefer G (2001) Early diagenesis of organic matter from sediments of the eastern subtropical Atlantic: evidence from stable nitrogen and carbon 
isotopes. Geochim Cosmochim Acta 65:1795-1808

25. Gyaneshwar P, Kumar GN, Parekh LJ, Poole PS (2002) Role of soil microorganisms in improving P nutrition of plants. Plant Soil 245:83-93

26. Hanba YT, Fujino M, Ushijima H, Kazama T, Kagotani Y (2010) Application of stable carbon isotopes to plant physiological processes and urban ecosystems. In: Ohkouchi N, Tayasu I, Koba K (eds) Earth, life, and isotopes. Kyoto University press, Kyoto, Japan, pp 53-70

27. Inoue T (2018) Carbon sequestration in mangroves. In: Kuwae T, Hori M (eds) Blue carbon in shallow coastal ecosystems: carbon dynamics, policy, and implementation. Springer, Singapore, pp 73-99

28. Inoue T, Nohara S, Takagi H, Anzai Y (2011a) Contrast of nitrogen contents around roots of mangrove plants. Plant Soil 339:471-483

29. Inoue T, Matsumoto K, Nohara S, Anzai Y (2011b) What happens to soil chemical properties after mangrove plants colonize? Plant Soil 346: 259 - 273

30. Inoue T, Khozu A, Shimono A (2019) Tracking the route of atmospheric nitrogen to diazotrophs colonizing buried mangrove roots. Tree Physiol 39:1896-1906

31. Inoue T, Shimono A, Akaji Y, Baba S, Takenaka A, Chan HT (2020) Mangrove-diazotroph relationships at the root, tree and forest scales: diazotrophic communities create high soil nitrogenase activities in Rhizophora stylosa rhizospheres. Ann Bot 125:131-144

32. Inoue T, Akaji Y, Noguchi K (2022) Distinct responses of growth and respiration to growth temperatures in two mangrove species. Ann Bot 129:15-28

33. Kainuma M, Baba S, Oshiro N, Kezuka M, Chan HT (2013) Current status of mangrove worldwide. Glob Environ Res 17:147-154

34. Khan MA, Aziz I (2001) Salinity tolerance in some mangrove species from Pakistan. Wetl Ecol Manag 9:219-223

35. Kohzu A, Miyajima T, Tayasu I, Yoshimizu C, Hyodo F, Matsui K, Nakano T, Wada E, Fujita N, Nagata T (2008) Use of stable nitrogen isotope signatures of riparian macrophytes as an indicator of anthropogenic $\mathrm{N}$ inputs to river ecosystems. Environ Sci Technol 42:7837-7841

36. Kothamasi D, Kothamasi S, Bhattacharyya A, Kuhad R, Babu C (2006) Arbuscular mycorrhizae and phosphate solubilizing bacteria of the rhizosphere of the mangrove ecosystem of Great Nicobar island, India. Biol Fertil Soils 42:358-361

37. Lin G, Sternberg LSL (1993) Effects of salinity fluctuation on photosynthetic gas exchange and plant growth of the red mangrove (Rhizophora mangle L.). J Exp Bot 44:9-16

38. López-Hoffman L, DeNoyer JL, Monroe IE, Shaftel R, Anten NPR, Martínez-Ramos M, Ackerly DD (2006) Mangrove seedling net photosynthesis growth and survivorship are interactively affected by salinity and light. Biotropica 38:606-616

39. Mariotti A, Mariotti F, Champigny M-L, Amargar N, Moyse A (1982) Nitrogen isotope fractionation associated with nitrate-reductase activity and uptake of $\mathrm{NO}_{3}{ }^{-}$by pearl millet. Plant Physiol 69:880884 
40. McMillan C (1971) Environmental factors affecting seedling establishment of the black mangrove on the central Texas coast. Ecol 52:927-930

41. Middelburg JJ, Nieuwenhuize J (1998) Carbon and nitrogen stable isotope in suspended matter and sediments from the Schelde Estuary. Mar Chem 60:217-225

42. Miyajima T, Hamagichi M (2018) Carbon sequestration in sediment as an ecosystem function of seagrass meadows. In: Kuwae T, Hori M (eds) Blue carbon in shallow coastal ecosystems: carbon dynamics, policy, and implementation. Springer, Singapore, pp 33-71

43. Mori N, Chang CW, Inoue T, Akaji Y, Hinoikidani K, Baba S, Takagi M, Mori S, Koike H, Miyauchi M, Suganuma R, Sabunas A, Miyashita T, Shimura T (2022) Parameterization of mangrove root structure of Rhizophora stylosa in coastal hydrodynamic model. Front Built Environ. https://doi.org/10.3389/fbuil.2021.782219

44. Ong JE, Gong WK (2013) Structure, function and management of mangrove ecosystems. ISME Mangrove Educational Book Series No. 2. International Society for Mangrove Ecosystems (ISME), Okinawa, Japan, and International Tropical Timber Organization (ITTO), Yokohama, Japan

45. Paludan C, Morris JT (1999) Distribution and speciation of phosphorus along a salinity gradient in intertidal marsh sediments. Biogeochemistry 45:197-221

46. Parida AK, Das AB (2004) Effects of $\mathrm{NaCl}$ stress on nitrogen and phosphorous metabolism in a true mangrove Bruguiera parviflora grown under hydroponic culture. J Plant Physiol 161:921-928

47. Parida AK, Das AB, Mittra $B$ (2004) Effects of salt on growth, ion accumulation, photosynthesis and leaf anatomy of the mangrove, Bruguiera parviflora. Trees 18:167-174

48. Passioura JB, Ball MC, Knight JH (1992) Mangroves may salinize the soil and in so doing limit their transpiration rate. Funct Ecol 6:476-481

49. Peters KE, Sweeney RE, Kaplan IR (1978) Correlation of carbon and nitrogen stable isotope ratios in sedimentary organic matter. Limnol Oceanogr 23:598-604

50. Pi N, Tam NFY, Wu Y, Wong MH (2009) Root anatomy and spatial pattern of radial oxygen loss of eight true mangrove species. Aquat Bot 90:222-230

51. Pi N, Tam NFY, Wong MH (2010) Effects of wastewater discharge on formation of Fe plaque on root surface and radial oxygen loss of mangrove roots. Environ pollut 158:381-387

52. Prasad MBK, Ramanathan AL (2010) Characterization of phosphorus fractions in the sediments of a tropical intertidal mangrove ecosystem. Wetl Ecol Manag 18:165-175

53. R Core Team (2018) R: a language and environment for statistical computing. R Foundation for Statistical Computing, Vienna, Austria. https://www.R-project.org/

54. Raymond NS, Gómez-Muñoz B, van der Bom FJT, Nybroe O, Jensen LS, Müller-Stöver DS, Oberson A, Richardson A (2021) Phosphate-solubilising microorganisms for improved crop productivity: a critical assessment. New Phytol 229:1268-1277

55. Samson MS, Rollon RN (2008) Growth performance of planted mangroves in the Philippines: Revisiting forest management strategies. Ambio 37:234-240 
56. Sanderman J, Hengl T, Fiske G, Solvik K, Adame MF, Benson L, Bukoski JJ, Carnell P, Cifuentes-Jara M, Donato D, Duncan C, Eid EM, Ermgassen P, Lewis CJE, Macreadie PI, Glass L, Gress S, Jardine SL, Jones TG, Nsombo EN, Rahman MM, Sanders CJ, Spalding M, Landis E (2018) A global map of mangrove forest soil carbon at 30m spatial resolution. Environ Res Lett 13:055002

57. Scholander PF (1968) How mangroves desalinate water. Physiol Plant 21:251-261

58. Scholander PF, Hammel HT, Hemmingsen E, Garey W (1962) Salt balance in mangroves. Plant Physiol 37:722-729

59. Scholander PF, Bradstreet ED, Hammel HT (1966) Sap concentrations in halophytes and some other plants. Plant Physiol 41:529-532

60. Sillanpää M, Vantellingen J, Friess DA (2017) Vegetation regeneration in a sustainably harvested mangrove forest in West Papua, Indonesia. For Ecol Manag 390:137-146

61. Tomlinson PB (2016) The botany of mangroves. Cambridge University Press, New York, USA

62. Van Steenis CGGJ (1984) Three more mangrove trees growing locally in nature in freshwater. Blumea 29:395-397

63. Vazquez P, Holguin G, Puente ME, Lopez-Cortes A, Bashan Y (2000) Phosphate-solubilizing microorganisms associated with the rhizosphere of mangroves in a semiarid coastal lagoon. Biol Fertil Soils 30:460-468

64. Wada E, Minagawa M, Mizutani H, Tsuji T, Imaizumi R, Karasawa K (1987) Biochemical studies on the transport of organic matter along the Otsuchi River watershed, Japan. Estuar Coast Shelf Sci 25:321-336

65. Wang W, Yan Z, You S, Zhang Y, Chen L, Lin G (2011) Mangroves: obligate or facultative halophytes? A review. Trees 25:953-963

66. Werner A, Stelzer A (1990) Physiological responses of the mangrove Rhizophora mangle grown in the absence of presence of $\mathrm{NaCl}$. Plant Cell Environ 13:243-255

67. Woodroffe CD (1988) Relict mangrove stand on Last Interglacial terrace, Chrismas Island, Indian Ocean. J Trop Ecol 4:1-17

68. Ye Y, Tam NFY, Wong YS, Lu CY (2003) Growth and physiological responses of two mangrove species (Bruguiera gymnorrhiza and Kandelia candel) to waterlogging. Environ Exp Bot 49:209-221

69. Yoneyama $T$ (1995) Nitrogen metabolism and fractionation of nitrogen isotopes in plants. In: Wada E, Yoneyama T, Minegawa M, Ando T, Fry BD (eds) Stable Isotopes in the Biosphere. Kyoto University Press, Japan, pp 92-102

70. Yoneyama T, Matsumaru T, Usui K, Engelaar WMHG (2001) Discrimination of nitrogen isotopes during absorption of ammonium and nitrate at different nitrogen concentrations by rice (Oriyza sativa L.) plants. Plant Cell Environ 24:133-139

\section{Figures}




\section{Figure 1}

Location of the study area. Google Earth image of (a) the Republic of Kiribati atolls, (b) Tarawa atoll, (c) location of Bonriki (square), (d) locations of afforestation stand and mangrove forest where propagules were collected (squares), and (e) afforestation stand. Numbers in (e) correspond to the patch ID in Table 1. Hatched areas in (e) indicate that no surviving tree was observed in 2019.

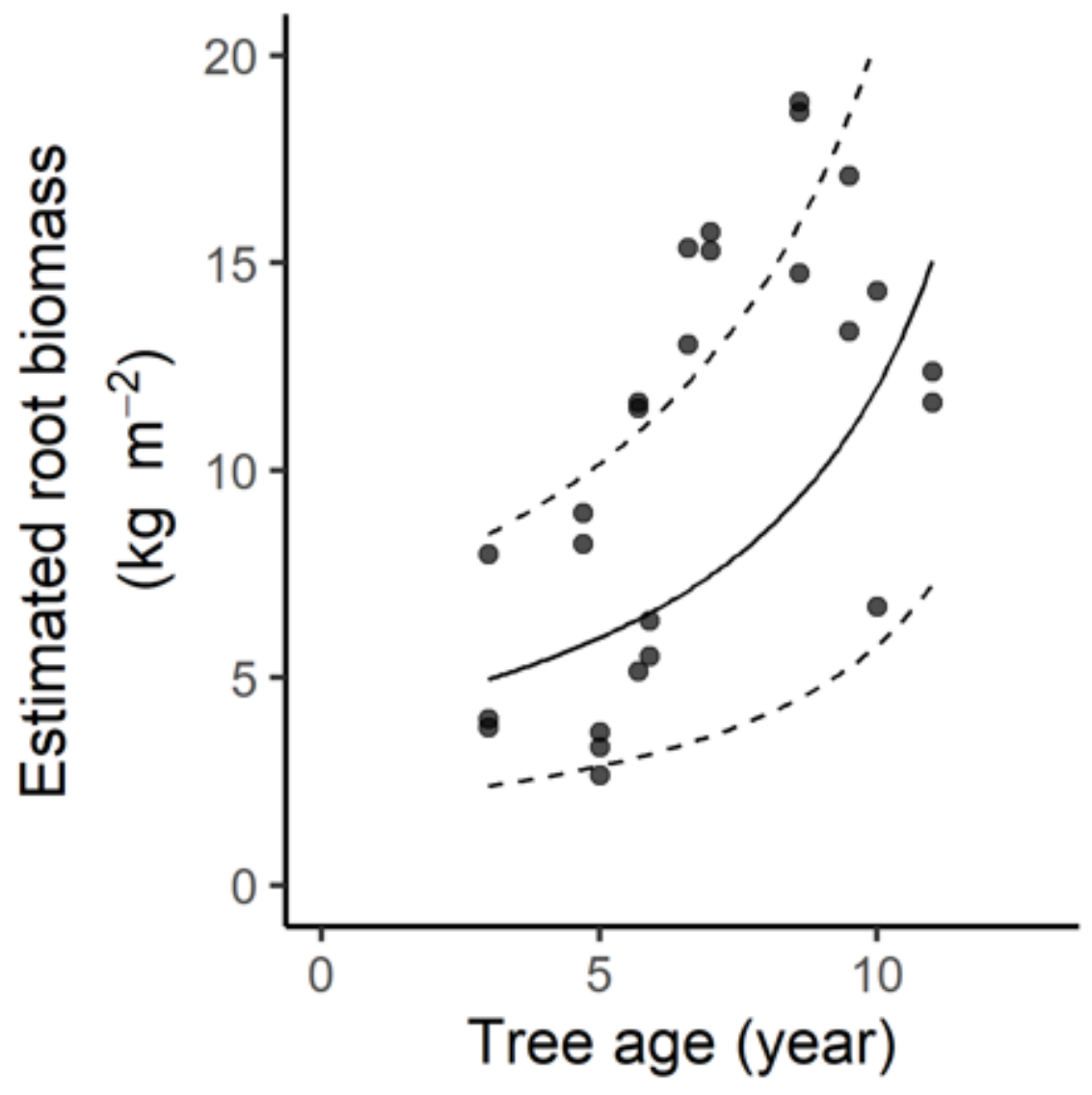

Figure 2

Relationship between tree age and estimated root biomass. Points indicate data of each subplot. Solid line is fitted model selected by GLMM analysis, and dashed lines indicate $95 \%$ prediction intervals. 


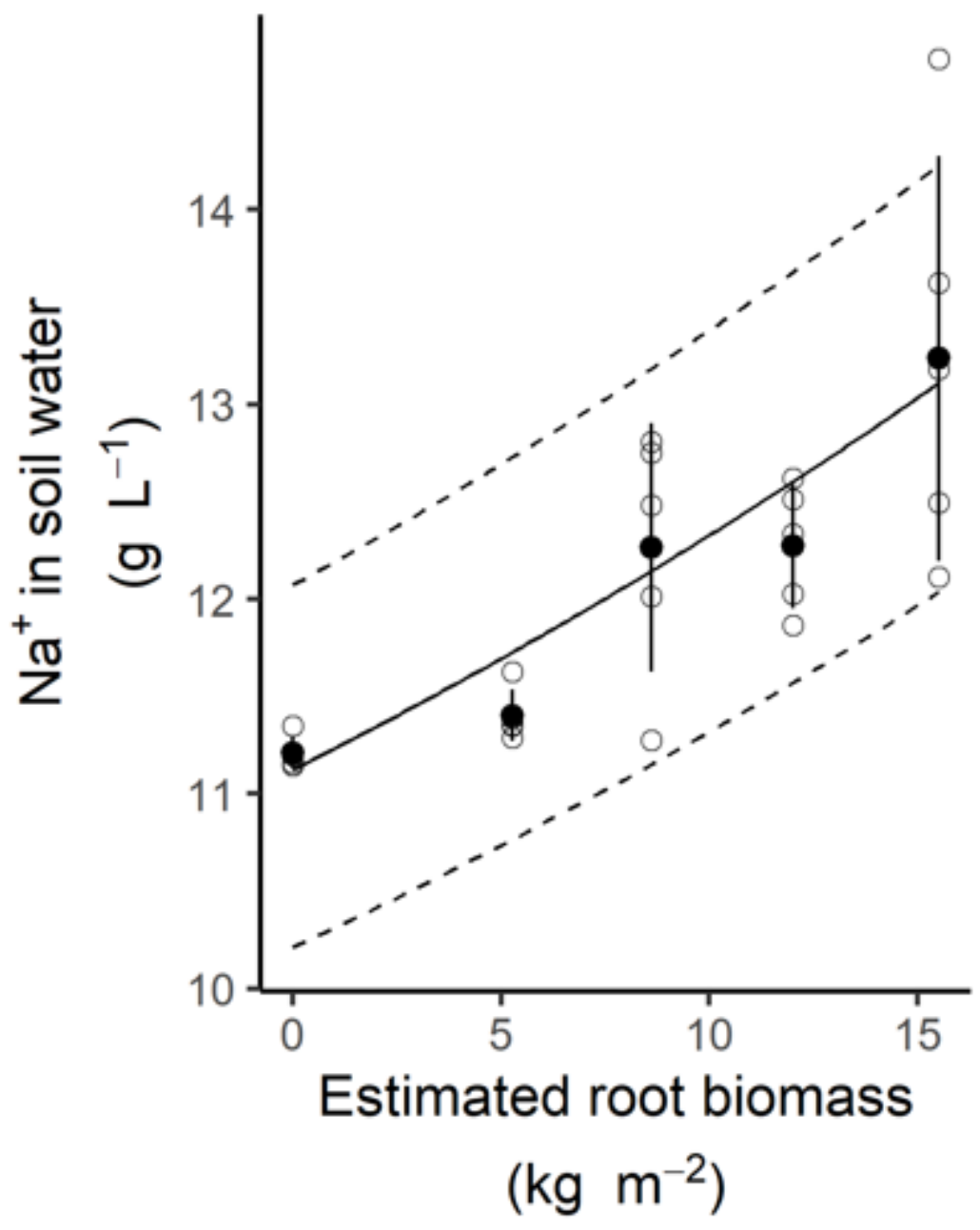

Figure 3

Relationship between estimated root biomass and dissolved $\mathrm{Na}^{+}$concentration in soil pore water. Open points indicate raw data, and black points indicate mean values. Bars indicate standard deviations $(N=$ 5). Solid line is fitted model selected by GLMM analysis, and dashed lines indicate $95 \%$ prediction intervals.

(a) DTP_pore

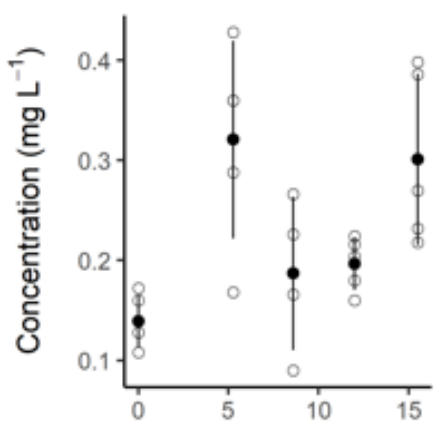

(b) DOP_pore

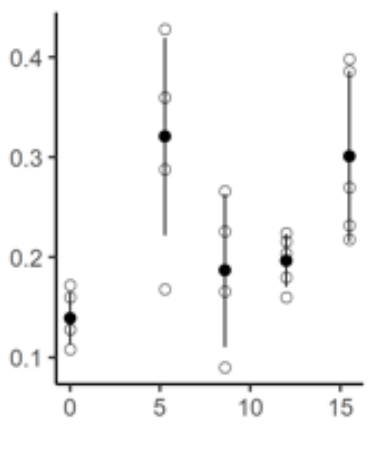

Estimated root biomass $\left(\mathrm{kg} \mathrm{m}^{-2}\right)$ (c) $\mathrm{PO}_{4}^{-}-\mathrm{P} \_$pore

(d) $\mathrm{PO}_{4}-\mathrm{P}: \mathrm{DTP}$
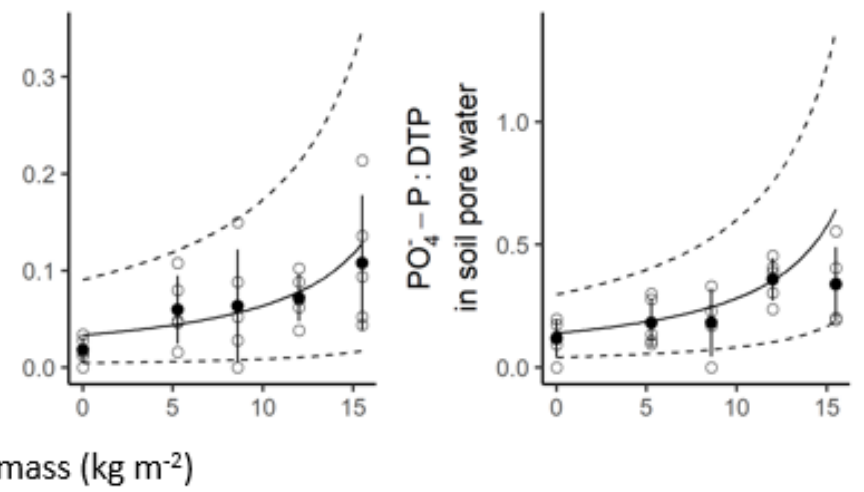
Figure 4

Relationship between estimated root biomass and (a) dissolved total phosphorus, (b) dissolved organic phosphorus, (c) $\mathrm{PO}_{4}{ }^{-} \mathrm{P}$, and (d) $\mathrm{PO}_{4}-\mathrm{P}$ :DTP concentration in soil pore water. For other details, see the legend of Figure 3.
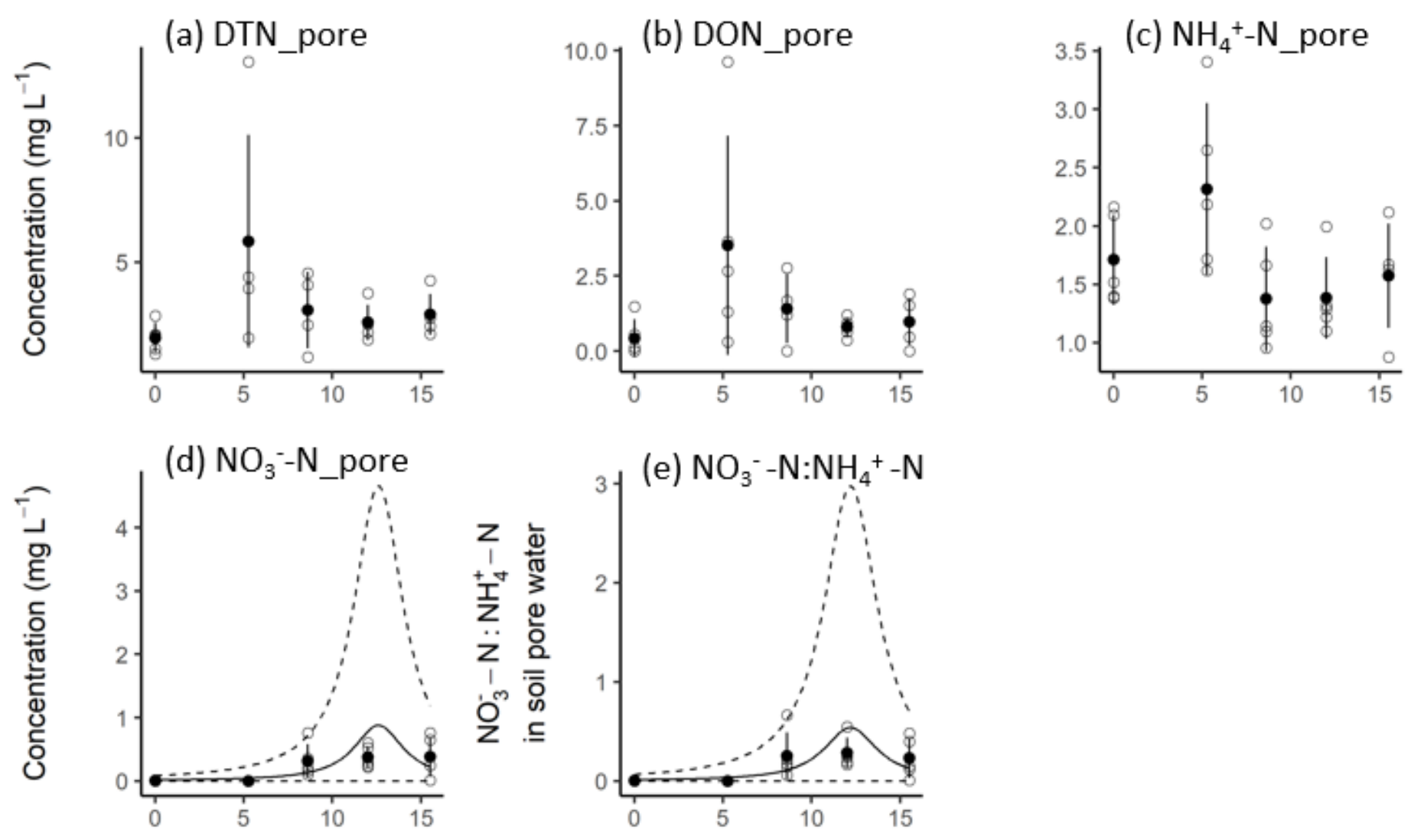

Estimated root biomass $\left(\mathrm{kg} \mathrm{m}^{-2}\right)$

\section{Figure 5}

Relationship between estimated root biomass and (a) dissolved total nitrogen, (b) dissolved organic nitrogen, (c) $\mathrm{NH}_{4}{ }^{+}-\mathrm{N}$, (d) $\mathrm{NO}_{3}{ }^{-}-\mathrm{N}$, (e) $\mathrm{NH}_{4}{ }^{+}-\mathrm{N}: \mathrm{DTN},(\mathrm{f}) \mathrm{NO}_{3}{ }^{-} \mathrm{-N}: \mathrm{DTN}$, and (g) $\mathrm{NO}_{3}{ }^{-}-\mathrm{N}^{-} \mathrm{NH}_{4}{ }^{+}-\mathrm{N}$ concentration in soil pore water. For other details, see the legend of Figure 3. 

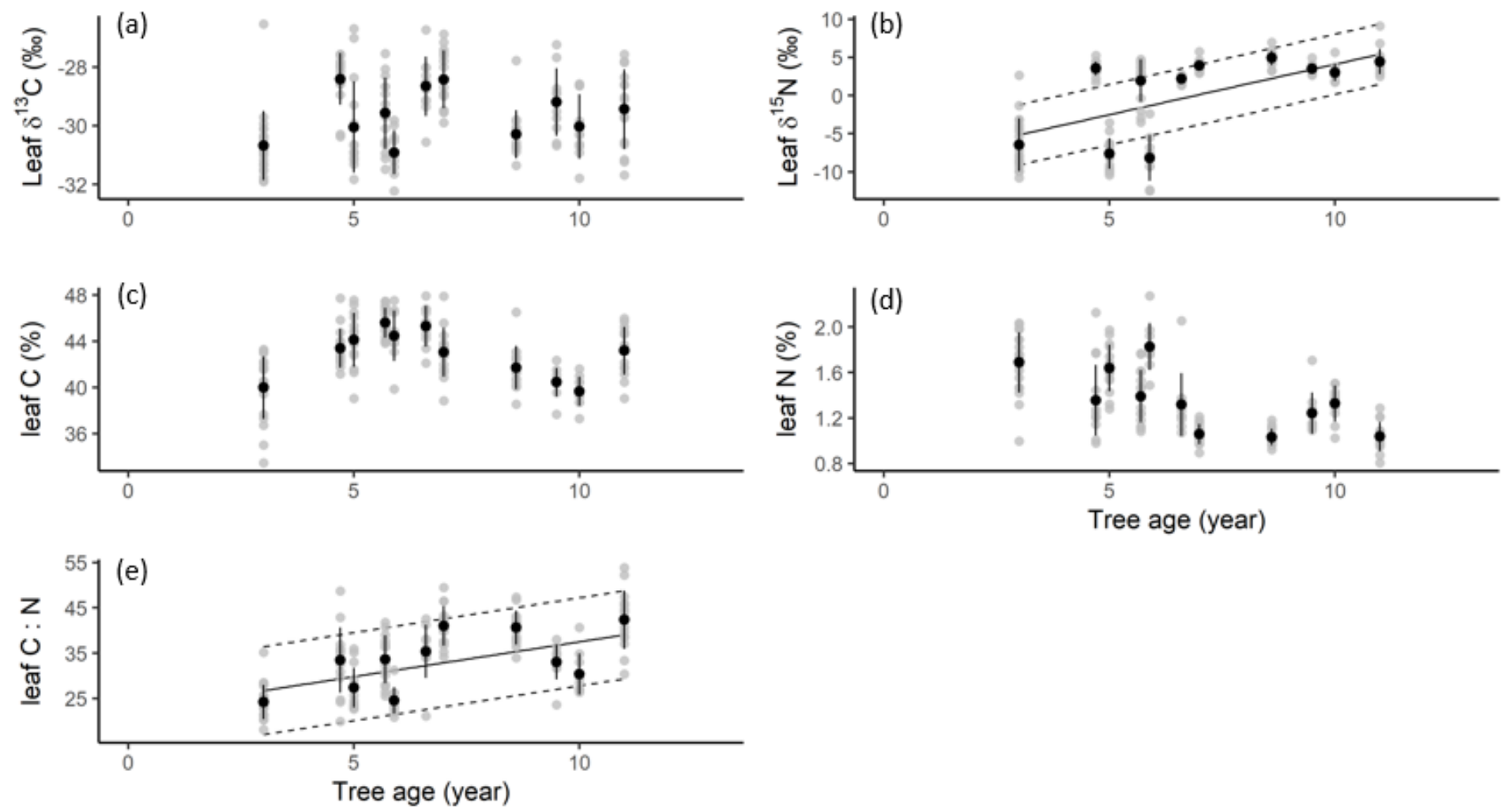

\section{Figure 6}

Relationship between tree age and (a) leaf $\delta^{13} \mathrm{C}(\%)$, (b) leaf $\delta^{15} \mathrm{~N}(\% \mathrm{o})$, (c) leaf carbon (\%), (d) leaf nitrogen (\%), and (e) leaf C:N. Grey points indicate raw data, and black points indicate mean values. Bars indicate standard deviations $(N=5)$. Solid line is fitted model selected by GLMM analysis, and dashed lines indicate $95 \%$ prediction intervals. 


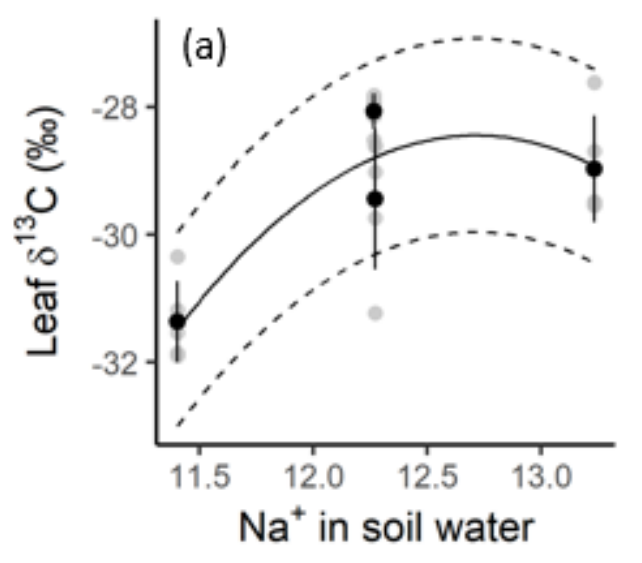

$\left(\mathrm{g} \mathrm{L}^{-1}\right)$

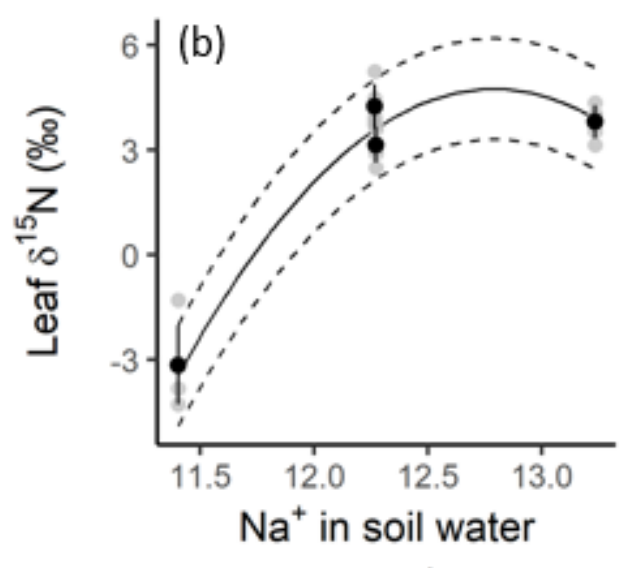

$\left(\mathrm{g} \mathrm{L}^{-1}\right)$

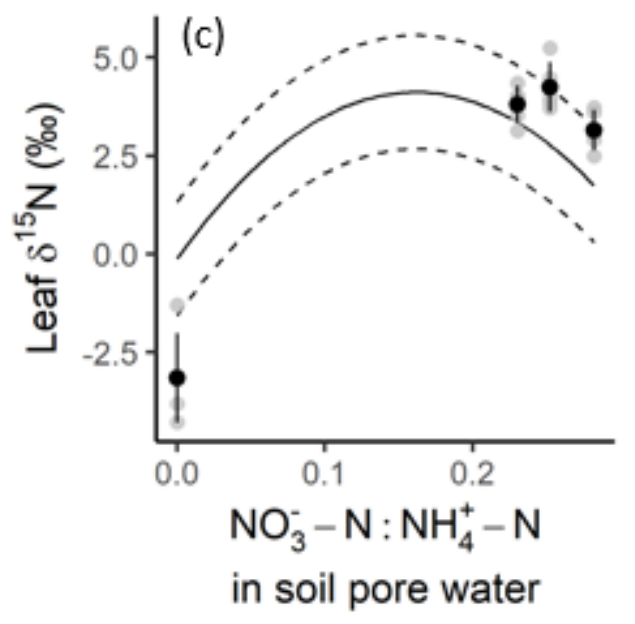

Figure 7

Relationship between sodium concentration in soil pore water and (a) leaf $\delta^{13} \mathrm{C}(\% \mathrm{o})$ and (b) leaf $\delta^{15} \mathrm{~N}$ (\%o); (c) relationship between $\mathrm{NO}_{3}-\mathrm{N}_{\mathrm{NH}_{4}} \mathrm{~N}$ in soil pore water and leaf $\delta^{15} \mathrm{~N}(\%)$. For other details, see the legend of Figure 6.

\section{Supplementary Files}

This is a list of supplementary files associated with this preprint. Click to download.

- InoueTableS1.xlsx

- SIFigures.pdf 